\title{
Essential Tremor with Aspartic Acidemia
}

\author{
SHIROH MIURA, RYUTA FUJIOKA* AND TAKAYUKI TANIWAKI \\ Division of Respirology, Neurology and Rheumatology, Department of Medicine, Kurume University School of \\ Medicine, Kurume 830-0011 and *Department of Food and Nutrition, \\ Верри University Junior College, Верри 874-8501, Japan \\ Received 4 August 2016, accepted 17 October 2016 \\ J-STAGE advance publication 15 March 2017
}

Edited by AKINORI NISHI

\begin{abstract}
Summary: We describe two cases of typical essential tremor with aspartic acidemia and mildly increased concentrations of plasma glutamic acid. Although this is a preliminary report, we emphasize the possibility of using amino acids, including aspartic acid, as biomarkers for the detection of essential tremor.
\end{abstract}

Key words essential tremor, aspartic acid, glutamic acid, amino acid, taurine

\section{INTRODUCTION}

Essential tremor (ET) is one of the most prevalent movement disorders [1,2], and $\gamma$-aminobutyric acid (GABA) is thought to be the main neurotransmitter involved in the ET pathophysiology. The amino acid glutamate has also been implicated in ET [3]. Although the amino acid aspartate is less potent than glutamate in excitatory neurotransmission under normal physiological conditions, aspartate is one of the two major endogenous excitatory amino acids [4], however, its pathogenic role in ET remains unknown. We describe here two cases of typical ET with aspartic acidemia and review the literature in this field.

\section{CASE REPORT}

Case 1 was a 42-year-old man (height: $175.9 \mathrm{~cm}$; weight: $75.7 \mathrm{~kg}$ ) who first noticed a nervous tremor and writing tremor at the age of 30 . A head tremor developed at the age of 38. There was no familial history of tremor. Excess sweating was observed on his palms and plantars. Neurological examination revealed no abnormalities, except for a fine head tremor at rest and a bilateral fine postural tremor of the finger. Serum thyroid stimulating hormone (TSH) and free T4 levels were normal. Anti-thyroglobulin antibody levels were negative. Plasma aspartic acid was $9.8 \mathrm{nmol} / \mathrm{ml}$ (normal: $<2.4 \mathrm{nmol} / \mathrm{ml}$ ), glutamic acid was $87.6 \mathrm{nmol} / \mathrm{ml}$ (normal: $12.6-62.5 \mathrm{nmol} / \mathrm{ml}$ ), taurine was $224.2 \mathrm{nmol} /$ $\mathrm{ml}$ (normal: $39.5-93.2 \mathrm{nmol} / \mathrm{ml}$ ), asparagine was 42.4 $\mathrm{nmol} / \mathrm{ml}$ (normal: $44.7-96.8 \mathrm{nmol} / \mathrm{ml}$ ), and $\beta$-alanine was $4.6 \mathrm{nmol} / \mathrm{ml}$ (normal: trace). Blood levels of the other 34 amino acids were within or near their normal ranges (Table). Brain magnetic resonance imaging (MRI) demonstrated no abnormalities (Figure A, B).

Case 2 was a 71-year-old woman (height: $154 \mathrm{~cm}$, weight: $52 \mathrm{~kg}$ ) who first noticed a head tremor at the age of 65 . She had no family history of tremor. Upon examination, a head tremor was observed at rest, as well as a bilateral postural and kinetic hand tremor. Serum TSH, free T3, and free T4 levels were normal. Plasma aspartic acid was $4.7 \mathrm{nmol} / \mathrm{ml}$, glutamic acid was $65.1 \mathrm{nmol} / \mathrm{ml}$, taurine was $116.1 \mathrm{nmol} / \mathrm{ml}$, and asparagine was $44.3 \mathrm{nmol} / \mathrm{ml}$. Blood levels of the other 35 amino acids were near their normal ranges (Table). Brain MRI revealed no definitive evidence of abnormality (Figure C, D). 


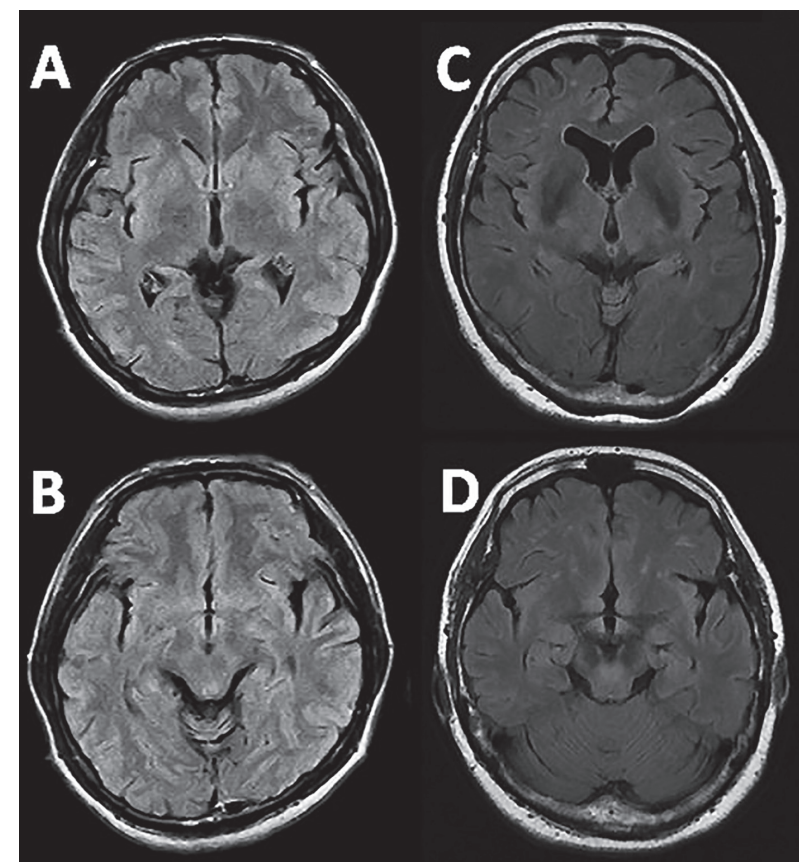

Figure. No abnormality was detected in the midbrain or basal ganglia by fluid attenuation inversion recovery (FLAIR) images. A, B) Case 1; C, D) Case 2.

\section{DISCUSSION}

In the two cases presented, increased concentrations of plasma aspartic acid, taurine, and glutamic acid were observed. There was also a slightly reduced concentration of asparagine.

$\mathrm{N}$-methyl-D-aspartate (NMDA) receptors are major ionotropic glutamate receptors composed of two obligatory GluN1 and two modulatory GluN2 (A-D) subunits located at excitatory synapses in the central nervous system [5]. ET is thought to be associated with the dysregulation of NMDA pathways [6]. Although one report suggested that aspartate does not contribute to excitatory synaptic transmission in CA1 pyramidal neurons [7], aspartate has been shown to act as an agonist to NMDA receptors [8]. The Aspa gene which encodes aspartoacylase, hydrolyzing N-acetyl-L-aspartic acid to aspartate and acetate, is thought to be essential for generating ET [9]. Therefore, aspartate could play an important role in the pathogenesis of ET.

It is conceivable that elevated concentrations of plasma aspartic acid are associated with raised plasma glutamic acid levels. Indeed, in a previous study, serum glutamate and aspartate levels were significantly increased in patients with ET compared with controls [10]. Unlike glutamate, opposite changes in the level of aspartate in cerebrospinal fluid were detected in patients with ET [10]. This suggests that aspartic acid could be broken down in the central nervous system of ET patients.

Only one previous study has reported that the concentration of taurine does not differ significantly in ET patients compared with controls [10]. This contrasts with the finding in our two present cases. Taurine not only has a neuroprotective function in reducing the calcium influx from various calcium channels, including NMDA receptors, but also inhibits the apoptosis cascade [11]. We speculate that taurine levels increase reactively to protect neurons.

In conclusion, aspartic acidemia and/or glutamic acidemia could be associated with ET. Future work should compare the concentrations of amino acids among several neurological diseases such as ET, spinocerebellar ataxia, and Parkinson's disease with or without tremor to determine whether amino acids such as aspartic acid and glutamic acid could be used as biomarkers of ET.

ACKNOWLEDGMENTS: We thank Jason R Gibson (Duke University Medical Center, Durham, NC, USA) for his advice on this manuscript.

DISCLOSURE OF CONFLICTS OF INTEREST: The authors declare no financial or other conflicts of interest.

AUTHORS' CONTRIBUTIONS: SM was the main contributor to manuscript preparation. RF and TT drafted and revised the manuscript.

\section{REFERENCES}

1. Louis ED, and Ferreira JJ. How common is the most common adult movement disorder? Update on the worldwide prevalence of essential tremor. Mov Disord 2010; 25:534541

2. Louis ED. Essential tremor: from bedside to bench and back to bedside. Curr Opin Neurol 2014; 27:461-467.

3. Marin-Lahoz J, and Gironell A. Linking essential tremor to the cerebellum: neurochemical evidence. Cerebellum 2016; 15:243-252.

4. Ogata T, Nakamura Y, Tsuji K, Okumura H, Kataoka K et al. Role of aspartate in ischemic spinal cord damage. J Orthop Res 1996; 14:504-510.

5. Fan X, Jin WY, and Wang YT. The NMDA receptor complex: a multifunctional machine at the glutamatergic synapse. Front Cell Neurosci 2014; 8:160.

6. Manto M, and Laute MA. A possible mechanism for the beneficial effect of ethanol in essential tremor. Eur J Neurol 2008; 15:697-705.

7. Herring BE, Silm K, Edwards RH, and Nicoll RA. Is aspartate an excitatory neurotransmitter? J Neurosci 2015; 35:10168-10171.

8. Chen PE, Geballe MT, Stansfeld PJ, Johnston AR, Yuan H et al. Structual features of the glutamate binding site in 
TABLE

The plasma concentration of amino acids of two present patients

\begin{tabular}{|c|c|c|c|}
\hline Amino acids & Case 1 & Case 2 & Normal value $(\mathrm{nmol} / \mathrm{ml})$ \\
\hline Aspartic acid & 9.8 & 4.7 & $\leqq 2.4$ \\
\hline Glutamic acid & 87.6 & 65.1 & $12.6-62.5$ \\
\hline Taurine & 224.2 & 116.1 & $39.5-93.2$ \\
\hline Hydroxyproline & 11.4 & ND & $\leqq 21.6$ \\
\hline Threonine & 118.9 & 83.6 & $66.5-188.9$ \\
\hline Serine & 98.8 & 120.5 & $72.4-164.5$ \\
\hline Asparagine & 42.4 & 44.3 & $44.7-96.8$ \\
\hline Glutamine & 547.8 & 689.2 & $422.1-703.8$ \\
\hline Sarcosine & ND & ND & TR \\
\hline$\alpha$-Aminoadipic acid & TR & ND & $\mathrm{ND}$ \\
\hline Proline & 133.6 & 87.7 & $77.8-272.7$ \\
\hline Glycine & 177.2 & 285.8 & $151.0-351.0$ \\
\hline Alanine & 355.4 & 268.1 & $208.7-522.7$ \\
\hline Citrulline & 27.9 & 35.1 & $17.1-42.6$ \\
\hline$\alpha$-Aminobutyric acid & 14.7 & 9.1 & $7.9-26.6$ \\
\hline Valine & 230.3 & 167.5 & $147.8-307.0$ \\
\hline Cystine & 16.6 & 37.4 & 13.7-28.3 for Case 1, 29.4-48.7 for Case 2 \\
\hline Cystathionine & ND & ND & $\mathrm{TR}$ \\
\hline Methionine & 23.5 & 20.1 & $18.9-40.5$ \\
\hline Isoleucine & 58.3 & 44.1 & $43.0-112.8$ \\
\hline Leucine & 124.3 & 84.4 & $76.6-171.3$ \\
\hline Tyrosine & 56.7 & 58.1 & $40.4-90.3$ \\
\hline Phenylalanine & 53.9 & 46.2 & $42.6-75.7$ \\
\hline$\gamma$-Amino $\beta$-hydroxybutyric acid & ND & ND & ND \\
\hline$\beta$-Alanine & 4.6 & ND & $\mathrm{TR}$ \\
\hline$\beta$-Amino-iso-butyric acid & ND & TR & TR \\
\hline$\gamma$-Aminobutyric acid & ND & ND & ND \\
\hline Monoethanolamine & 7.7 & ND & $\leqq 10.4$ \\
\hline Homocystine & ND & $\mathrm{ND}$ & $\mathrm{ND}$ \\
\hline Histidine & 81.3 & 75.1 & $59.0-92.0$ \\
\hline 3-Methylhistidine & $\mathrm{TR}$ & ND & $\leqq 5.0$ \\
\hline 1-Methylhistidine & ND & ND & $\leqq 18.5$ \\
\hline Carnosine & ND & ND & ND \\
\hline Anserine & ND & ND & ND \\
\hline Tryptophan & 55.2 & 38.7 & $37.0-74.9$ \\
\hline Hydroxylysine & ND & ND & ND \\
\hline Ornithine & 87.8 & 88.1 & $31.3-104.7$ \\
\hline Lysine & 206.8 & 179.1 & $108.7-242.2$ \\
\hline Arginine & 54.3 & 62.3 & $53.6-133.6$ \\
\hline
\end{tabular}

ND: not detected, TR: trace

Normal values were cited from SRL.Inc. 
recombinant NR1/NR2A N-methyl-D-aspartate receptors determined by site-directed mutagenesis and molecular modeling. Mol Pharmacol 2005; 67:1470-1484.

9. Ohno Y, Shimizu S, Tatara A, Imaoku T, Ishii T et al. Hen1 is a tremorgenic genetic component in a rat model of essential tremor. PLoS One 2015; 10:e0123529.
10. Málly J, Baranyi M, and Vizi ES. Change in the concentrations of amino acids in CSF and serum of patients with essential tremor. J Neural Transm 1996; 103:555-560.

11. Wu JY and Prentice H. Role of taurine in the central nervous system. J Biomed Sci 2010; 17:S1. 